\title{
Família centro do mundo, descida ao inferno, renascimento e queda: o imaginário movido pelo rockumentary Cobain: Montage of Heck
}

\author{
Danilo Fantinel*
}

Cobain: Montage of Heck (EUA, 2015, $145 \mathrm{~min}$ )

Direção e roteiro: Brett Morgen

Fotografia: im Whitaker, Nicole Hirsch Whitaker

Edição: Joe Beshenkovsky, Brett Morgen

Música: Jeff Danna

Estúdio: HBO Documentary Films, Primary Wave Management, Public Road

Productions

Produção: Brett Morgen, Danielle Renfrew

Elenco: Don Cobain, Jenny Cobain, Kim Cobain, Kurt Cobain, Courtney

Love, Tracey Marander, Krist Novoselic, Wendy O'Connor, Pat Smear

Em 1994, quando Kurt Cobain cometia suicídio aos 27 anos, em Seattle, nos Estados Unidos, após uma vida de excessos e sofrimento, fãs de música ainda compravam CDs em quase todo mundo. Porém, se no início dos anos 2000 a venda de discos caiu com o fortalecimento das trocas de arquivo digital entre pessoas, ${ }^{1} \mathrm{o}$ interesse provocado pelos músicos, por suas canções e por sua vida não diminuiu. O culto a roqueiros se mantém, reforçando a noção de que a origem desta adoração não está centralizada somente na potência capitalista de gravadoras que giravam a cadeia produtiva e consumidora de rock, mas principalmente no apelo cultural, simbólico e potencialmente mítico provocado pelos artistas e por seu estilo de vida.

O entendimento sobre o fascínio, o culto e o consumo de rock'n'roll e de rock stars pode ganhar novas dimensões se problematizado em função dos Estudos do Imaginário preconizados pela Escola de Grenoble, que como heurística oferecem conhecimentos adicionais ao saber já constituído por outras

* Mestrando. Universidade Federal do Rio Grande do Sul - UFRGS, Faculdade de Biblioteconomia e Comunicação, Programa de Pós-Graduação em Comunicação e Informação - PPGCOM. 90430-181, Porto Alegre, Brasil. E-mail: danilo.fantinel@gmail.com

1. Em 1997, a indústria fonográfica brasileira rendeu $\mathrm{R} \$ 1,3$ bilhão, soma repetida no ano seguinte devido às vendas de discos de axé, sertanejo, pagode e pop. Em 2001, o montante foi reduzido para $\mathrm{R} \$ 998$ milhões. Em 2012, caiu para $\mathrm{R} \$ 373,2$ milhões. O Brasil desceu no ranking mundial de vendas do $5^{\circ}$ lugar em 1997 para o $12^{\circ}$ em 2012. Fonte: http://cultura.estadao.com.br. 
áreas de pesquisa. A partir de uma leitura simbólica do documentário Cobain: Montage of Heck (2015) atenta ao trajeto antropológico (Durand, 2012) que dá origem às imagens, buscamos revelar o imaginário movimentado pelo guitarrista Kurt Cobain, ex-líder da banda Nirvana, levando em conta, essencialmente, ${ }^{2}$ as informações apresentadas pelo filme de Brett Morgen lançado em 2015.

Conforme Gilbert Durand (2012), o imaginário humano se coloca como um grande sistema de imagens simbólicas de raízes arquetípicas e perfil polissêmico que estimulam constelações de simbolismos variados conectados a três grandes estruturas: a Heroica, ligada ao Regime Diurno das imagens (dimensão simbólica de forma geral cortante e virilizada), a Mística e a Dramática, ambas inseridas no Regime Noturno (com teor mais receptivo e uterino). Durand (2000, p. 99 e 100) entende que este imaginário antropológico possibilita ao sujeito lidar com suas angústias essenciais, oriundas da passagem do tempo e da consciência da morte, cumprindo assim um papel psicossocial equalizador. Para o autor, o homem cria imagens como técnica de defesa simbólica contra a inevitabilidade da morte.

Promotor de enraizamento antropológico, o imaginário estabelece uma correspondência com estruturas simbólicas antepassadas, pois o homem contemporâneo atualiza imagens pregnantes e repete mitos antigos em seu comportamento. Compartilhando deste imaginário, o sujeito propõe sentidos a sua experiência que variam conforme as interações entre sua subjetividade e seu meio sociocultural. Durand (2012: 41) entende que as imagens simbólicas são resultantes desta confluência, deste trajeto antropológico de ordem dual e recíproca, desta "[...] incessante troca [...] entre as pulsões subjetivas e assimiladoras e as intimações objetivas que emanam do meio cósmico e social". Ou seja, as imagens seguem uma constante antropológica que coloca em relação as condutas inerentes à condição humana e as coerções histórico-sociais.

Em retroalimentação permanente, o imaginário é nutrido por novas imagens ao mesmo tempo em que tem seus conteúdos refletidos, tanto na conduta dos indivíduos quanto em sua produção cultural e midiática.

\section{Do documentário ao imaginário}

Duas das expressões artísticas mais populares, música e cinema são linguagens pelas quais o homem elabora e debate ideias sobre si e seu ambiente. De acordo com Fernão Pessoa Ramos (2013), filmes documentários fazem representações sobre realidades e asserções sobre o mundo histórico independente-

2. Dados suplementares foram pesquisados em textos biográficos ou jornalísticos publicados no Brasil ou no exterior anteriormente. 
mente de seu tema, como ocorre com obras documentais sobre o rock'n'roll. Os chamados rockumentaries ou rock docs ${ }^{3}$ registram o cotidiano, o processo criativo, o culto e o consumo de artistas e bandas. Em seu percurso antropológico, roqueiros atuam como produtores de imagens técnicas ${ }^{4}$ (Flusser, 2011) e protagonistas de histórias que, se por um lado integram o repertório cultural compartilhado, por outro estimulam imagens simbólicas constitutivas do imaginário. Assim, instauram narrativas míticas contemporâneas marcadas por imagens arquetípicas (Jung, 2002) e símbolos (Eliade, 2002) recorrentes capazes de estruturar um imaginário rock que, por sua vez, está inserido ao imaginário humano como um todo. Nesta leitura simbólica sobre Cobain: Montage of Heck, buscamos revelar imagens, simbolismos e traços míticos evocados pela trajetória do ex-líder do Nirvana.

Foco de robusto debate acadêmico, este formato cinematográfico apresenta ainda hoje uma conceituação complexa, orbitando critérios sobre verdade, realidade e representação. Porém, seguindo Ramos, entendemos que documentários representam realidades e se posicionam sobre o mundo histórico a partir de elementos estéticos e narrativos. Portanto, devemos entendê-los não como espelhos de realidades, mas como filmes que montam discursos e imagens técnicas para operar representações fílmicas documentais - mesmo que estas sigam rigorosamente as intencionalidades e subjetividades de seus realizadores. Ainda assim, observamos que documentários registram a experiência do homem no mundo.

\section{Deuses da atualidade}

Ídolos de multidões transnacionais, as quais apresentam um estilo de vida desejado por muitos fãs, os roqueiros assumiram a posição de heróis em uma cultura pop que, desde seu início, atualiza culto e consumo como formas de reverência. Abordar o culto no que se refere à experiência da música se torna importante se pensarmos como José Miguel Wisnik (1999), que a entende como elemento coordenador das sociedades, atuando como mito fundador das culturas. Segundo sua antropologia do ruído:

Um único som afinado, cantado em uníssono por um grupo humano, tem o poder mágico de evocar uma fundação cósmica: insemina-se coletivamente,

3. O documentário de rock, também chamado rockumentary ou rock doc, guarda semelhança com o Cinéma Vérité francês e com o Direct Cinema norte-americano, propondo a verticalização no tratamento de seus temas.

4. Conforme Vilém Flusser, imagens técnicas são produzidas pelo homem com o auxílio de aparelhos, como fotografias, filmes ou vídeos. São imagens materiais, visuais, que dependem de alguma superfície. 
no meio dos ruídos do mundo, um princípio ordenador. [...] As sociedades existem na medida em que possam fazer música. (Wisnik,1999: 33-34).

O peso que o autor dá à música no processo de formação social lhe confere uma carga antropológica significativa no que diz respeito aos fundamentos das sociedades, despertando paralelismos com a concepção durandiana de imaginário como fundante da estrutura social. Tendo em vista que a música é uma das expressões culturais mais antigas da civilização, veículo de imagens poéticas oriundas do que Gaston Bachelard $(1990,2001)$ chama de imaginação criadora do homem, devemos então lembrar que a música tanto reflete quanto alimenta um imaginário arquetípico que, como capital cultural, dá sentido ao homem e à sociedade.

Sendo o homem produto de sua própria evolução cultural, os mitos tendem a emergir socialmente com frequência, mesmo que diluídos e degradados. Reatualizados, eles proporcionam graus diversos de sentidos que podem ser tanto apreendidos e interpretados pelo sujeito individualmente quanto apropriados e refletidos por produtos culturais e midiáticos. Residem aí os aspectos de recorrência mítica e de continuidade da mitologia ancestral na cultura atual dos quais fala Durand - posicionamentos estes que dialogam com o conceito de novo olimpiano proposto por Egdar Morin (1997), pelo qual o autor caracteriza os atuais artistas ou esportistas, por exemplo, como entidades míticas contemporâneas.

Morin vê nestes novos olimpianos os deuses da contemporaneidade, cujo papel mitológico lhes é conferido pela mídia. Dotados de dupla natureza, sendo uma humana, mortal, e outra sobre-humana, divina, são eles os novos modelos de comportamento e conduta. Se o teor humano permite a identificação dos admiradores, a porção supostamente divina garante o fascínio pelo ídolo. Nesta sobreposição de valores, a vida dos olimpianos interage com a vida cotidiana dos mortais, provocando neles um interesse constante por deidades midiáticas:

Os novos olimpianos são, simultaneamente, magnetizados no imaginário e no real, simultaneamente, ideais inimitáveis e modelos imitáveis; sua dupla natureza é análoga à dupla natureza teológica do herói-deus da religião cristã: olimpianas e olimpianos são sobre-humanos no papel que eles encarnam, humanos na existência privada que eles levam. A imprensa de massa, ao mesmo tempo em que investe os olimpianos de um papel mitológico, mergulha em suas vidas privadas a fim de extrair delas a substância humana que permite a identificação. (Morin, 1997: 106).

Olimpianos atuais, estrelas da mídia como artistas do cinema e da TV, músicos, top models e esportistas, ao se colocarem como ideais a serem seguidos, induzem o público ao consumo de bens (materiais ou não) cuja função, entre 
outras, é reforçar a lógica binária e cíclica de culto e consumo - culto este que nasce justamente dos papéis assumidos pelos novos olimpianos no trânsito entre o mundo histórico no qual vivem, lócus de sua natureza humana, e a esfera midiática que lhes confere o papel mitológico citado por Morin.

Pauta frequente da cobertura midiática, estes deuses da atualidade tornamse modelos de autorrealização adorados por massas de consumidores, fato que aponta sua importância à cultura popular contemporânea. Grifes de poder, novos olimpianos como os rock stars apresentam um estilo de vida cujas práticas são intensamente registradas em filmes documentários. São estes longasmetragens documentais que dão acesso aos fatos, histórias e condutas de bandas e cantores que, em última análise, emanam traços arquetípicos, imagens simbólicas e metáforas recorrentes instauradores de narrativas contemporâneas e de simbolismos constitutivos de um imaginário rock.

\section{Uma leitura de Cobain: Montage of Heck}

O título do documentário dirigido por Brett Morgen é inspirado na fita de áudio Montage of Heck ${ }^{5}$, gravada por Kurt Cobain em 1988. A colagem punk, supostamente aleatória, que mistura sons de programas de TV com vocalizações, experimentações de guitarra e efeitos técnicos, de certa forma também orienta a narrativa e a direção de arte do filme. Em seu longa-metragem, o cineasta articula diversos fragmentos do intenso período criativo de Kurt, como depoimentos do músico gravados em áudio, canções, anotações, textos e desenhos com home vídeos e filmes familiares cotidianos realizados em super-8. Assim, Morgen não apenas reconstrói o artista em função de seus artefatos como também resgata o homem que há por trás do guitarrista. Mais do que isso, documenta em filme o percurso antropológico de Kurt, movimentador de um imaginário próprio que, por sua vez, liga-se a um imaginário rock mais amplo, sendo ele parte do imaginário humano.

Cobain: Montage of Heck registra a vida pública e privada do músico, com relatos sobre sua infância, trechos de ensaios, shows, informações sobre a vida em família, o casamento, a paternidade, o processo criativo e a dependência química. Nesse sentido, a representação documental contempla as personas (Jung, 1978) social e artística de Kurt, bem como aspectos histórico-culturais da época retratada, contextualizando o indivíduo em seu meio. Curiosamente, logo no início do longa-metragem estas dimensões social e artística/midiática

5. Montagem dos Infernos poderia ser uma das traduções para o título da fita de áudio e do documentário. 
do roqueiro ${ }^{6}$ se encontram durante um show do Nirvana no qual Kurt encena sua própria morte sobre um grande palco. ${ }^{7}$ A morte simbólica do guitarrista, encenada no solo sagrado de qualquer artista, converge e ritualiza a representação da morte humana e a metáfora da morte mítica. A cena do filme é intercala com depoimentos da mãe de Kurt, Wendy, da irmã, Kim, e do ex-baixista do Nirvana, Krist Novoselic, todos ressaltando a genialidade do músico. Gênio este que, se por um lado iluminou seu poder criativo, por outro jogou sombras sobre seu caminho histórico e simbólico.

\section{Família, centro do mundo}

Levando em conta exclusivamente as informações e a documentação apresentadas no documentário Cobain: Montage of Heck, ${ }^{8}$ a trajetória de fatos e momentos marcantes que pontuam e orientam o percurso simbólico de Kurt Cobain tem início durante sua primeira infância (Figura 1) em Aberdeen, nos Estados Unidos, onde nasceu em 20 de fevereiro de 1967. Filho de Don Cobain e Wendy O'Connor, Kurt demonstrava ímpeto criativo e hiperatividade desde cedo. Além de brincar, mostrava interesse por desenho e canto, inventava pequenas músicas e improvisava shows caseiros com instrumentos musicais de brinquedo - como mostram fotografias e filmes antigos (Cobain: Montage of Heck, 2015, 06:45-12:20). ${ }^{9}$ Energético, estava sempre envolvido em algo. Ainda pequeno, um médico teria recomendado ritalina para tratar o que seria um transtorno psicológico em Kurt ${ }^{10}$. Provocando um efeito cumulativo, o medicamento o fez perder o controle ${ }^{11}$ durante o que teria sido uma longa noite.

6. Ou, como prefere Morin, a substância humana e o papel mitológico do músico propiciado pela mídia.

7. O fato ocorreu no megafestival inglês Reading em 1992.

8. É nossa a tradução do inglês para o português relativa a entrevistas, depoimentos, documentos sonoros ou textuais exibidos pelo filme.

9. A partir de agora todas as referências ao documentário Cobain: Montage of Heck terão seu título suprimido para evitar repetição. As referências a demais obras e autores serão devidamente informadas.

10. Não identificado pelo documentário, sendo citado por Wendy apenas o "diagnóstico" de hiperatividade.

11. De acordo com Wendy, Kurt "went off the rails" $(2015,10: 19)$. 


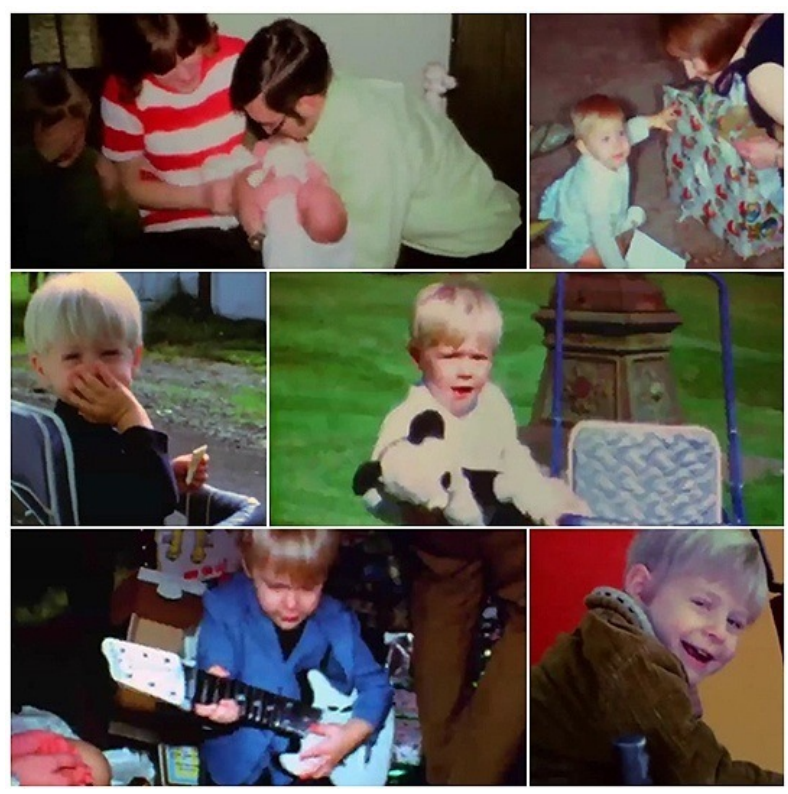

Figura 1. Imagens técnicas registram a imfância de Kurt Cobain.

Reproduções: Cobain: Montage of Heck (2015).

Consta que enquanto Don desaprovava a inquietação do filho, deixandoo constantemente magoado e constrangido, Wendy não conseguia controlá-lo sozinha. A situação do menino se tornou mais aguda aos nove anos, após a separação dos pais. Vivendo muitos anos com a mãe após o divórcio, Kurt seguiu desenvolvendo seu lado artístico ${ }^{12}$ e seu senso crítico ao mesmo tempo em que enfrentava dificuldades de relacionamento com colegas de escola, o que o deixava mais angustiado.

Desestabilizado pelo afastamento dos pais, suas duas principais referências de vida no mundo, e as duas pessoas que estimulam diretamente as imagens arquetípicas do Pai e de Mãe - cujas potencialidades simbólicas têm valorizações positivas e negativas concomitantemente -, Kurt dá início a um período de grande instabilidade quando Wendy, cansada do filho, manda-o morar com Don. Expulso pela própria mãe, Kurt tem um momento inicial positivo na nova casa, ao lado do pai, da madrasta Jenny e dos filhos dela, mas logo perceberia que aquela não era a sua família e que nela ele não tinha privilégios. Conforme Jenny, Kurt desejava muito ter uma família (2015: 13:55-14:22), mas queria também ser o mais amado, o centro das atenções, ficando contrariado quando

12. Conforme a madrasta, Jenny Cobain, Kurt já tocava guitarra quando morou na casa do pai, Don, por algum tempo na pré-adolescência (Figura 2). 
percebia uma realidade oposta. Após problemas entre as crianças, Don manda o filho embora. Assim, Kurt se afasta do pai novamente, passando a transitar entre casas de parentes sem fixar-se em lugar algum. Na escola, a pressão por aceitação continuava a atormentá-lo:

Em uma comunidade que reforça histórias sexuais de macho man como o ponto alto de todas as conversas, eu era um menino imaturo, mal desenvolvido, que nunca havia transado e que estava sempre a fim. Pobre garoto! Isso me incomodava, pois eu estava com tesão e sempre tinha que inventar histórias como "ah, quando tirei férias conheci uma menina, transamos e ela amou etc, etc". (Cobain: Montage of Heck, 2015: 18:45-19:18).

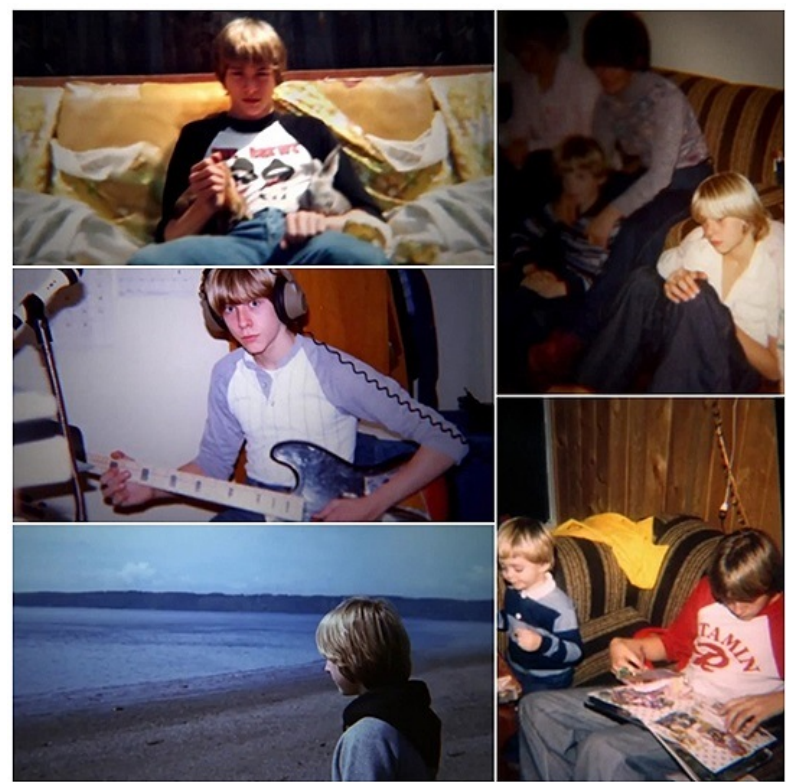

Figura 2. Durante a adolescência, Kurt Cobain torna-se mais introspectivo ao mesmo tempo em passa a tocar guitarra.

Reproduções: Cobain Montage of Heck (2015).

Com o tempo, Kurt passou a fumar maconha, droga que o ajudava a "[...] escapar o dia todo e não ter crises nervosas rotineiras" (2015: 19:50-20:00). Também começa a conviver com garotos brancos de classe média baixa, os quais classifica como junkies e white trash ${ }^{13}$ que passavam os dias se drogando e ingerindo bebidas alcoólicas roubadas da casa de uma menina considerada

13. Junkies, como são conhecidos os viciados em drogas pesadas ilícitas ou não, como álcool, pílulas, cocaína e heroína, especialmente. Já como white trash podem ser entendidos os integrantes brancos das classes baixas norte-americanas, habitantes de subúrbios pobres das metrópoles ou de pequenas cidades do interior, desvinculados de sistemas de assistência social 
por todos como "retardada" (2015: 20:48), mas que Kurt considerava apenas tímida. Foi com ela, a quem todos ridicularizavam, que ele teria perdido a virgindade. Em áudio gravado por Kurt e apresentado no documentário, o roqueiro afirma que queria transar antes de cometer suicídio $(2015,21: 30)$ para não morrer sem ter a experiência. Porém, o que era segredo se tornou público. Humilhado na escola, Kurt teria tentado o suicídio na linha ferroviária da cidade, porém teria escolhido os trilhos errados ao se deitar durante a passagem do trem das 23h (2015: 22:30-23:00).

A separação dos pais foi uma ruptura considerável na vida de Kurt, cujas rachaduras comprometem sua adolescência e se estendem até sua a fase adulta. O menino criativo, inteligente e ativo, que conquistava a todos, acompanhou não só a dissolução do casamento como também a ruína do próprio sonho de família que nutria e do qual necessitava. Da infância ascendente e solar, rica em afeto e energia, Kurt entra em um período marcado por anestesia e estagnação, sendo a puberdade e a adolescência manchadas por tons escuros de um tempo sombrio. Por volta dos 15 anos, já muito rebelde e ainda mais próximo das drogas, do álcool e da paranoia ${ }^{14}$, Kurt volta a morar com a mãe e a irmã, Kim, para quem o irmão gostava mesmo de normalidade e desejava ter uma família comum, “[...] com mãe, pai, crianças e tudo feliz”. Porém, diz que, ao mesmo tempo, Kurt "lutava contra isso". Segundo Kim, "[...] ele combatia o que realmente queria" (2015: 23:56-24:09).

Em termos simbólicos, a família Cobain se coloca para Kurt como o "centro do mundo" ligado ao simbolismo do centro do qual fala Mircea Eliade (2002). Neste simbolismo muito comum a culturas arcaicas, e ainda presente na sociedade contemporânea, o centro não é geométrico nem mesmo geográfico, mas simbólico, repleto de sentidos múltiplos e, ainda assim, similares. Símbolo de lócus energético presente no imaginário humano, transitando no ancestral inconsciente coletivo, este potente centro converge os três níveis cósmicos: Terra, Céu e Mundo Inferior. De fato, a definição deste centro por aqueles que compartilham deste simbolismo é tão importante que "equivale à Criação do Mundo"(Eliade, 1992: 17). No simbolismo do centro, o "centro do mundo" é também o ponto para onde o cosmo converge, ou ainda o local divino por excelência, onde o sagrado se manifesta sob a forma de hierofanias

como saúde e educação. Suscetíveis às drogas e ao crime, o white trash está à margem do american dream.

14. Kurt afirma em áudio no documentário: “[...] deixei os dois últimos meses de escola* Eu estava tão retraído e antissocial que eu estava quase maluco. Sabe, eu me sentia tão diferente e tão louco" (2015, 26:32-26:45). *Conforme o contexto do documentário, provavelmente seria o último ano escolar de Kurt, embora o filme não deixe clara a data em que o fato teria ocorrido. 
ou epifanias. Ou seja, simbolicamente, "centros do mundo" 15 proporcionam revelações de sentido e orientam a transcendência de imagens pregnantes que ilustram um grupo social, atualizando permanentemente o teor das mesmas e também as narrativas que oferecem entendimentos de mundo.

Um grande número de mitos, ritos, crenças e condutas pessoais que estruturam realidades derivam do simbolismo do centro, que se expressa também na vida do líder do Nirvana. Sendo o "centro do mundo" de Kurt um ideal de família que deixou de existir em sua vida, um sonho impossível da tríade pai-mãe-filho, vemos o simbolismo do centro movimentado pelo músico esvaziado em sua dimensão mais profunda: o próprio sentido de família. Quando Kurt perde o núcleo familiar perde igualmente seu centro. Este se torna então um "centro de mundo" fugidio, que não se encontra na casa da mãe nem na do pai nem nas casas dos tios nem em lugar algum, pois nenhum lugar é o lar de sua família, já que esta não existe mais. Com um centro em fuga, Kurt perde sua referência primeira, o seio familiar, a plataforma mais íntima de lançamento ao mundo - um mundo que agora recebe um jovem tão criativo quanto angustiado, propenso igualmente à música e à escrita quanto à depressão e às drogas.

A crise em cadeia leva Kurt à primeira tentativa de suicídio e configura também a primeira queda do músico, movimento estimulante do simbolismo catamórfico, pelo qual são ativadas imagens e sentidos de escuridão ameaçadora, trevas inescapáveis, medo, dor e desespero (Durand, 2012: 111 e 121). Esta queda simbólica, que no caso do guitarrista é tanto física quanto moral, ganha reflexos no uso de drogas e álcool, na infelicidade decorrente da incompreensão sobre o destino dos pais, nos problemas de relacionamento familiar e social. A imagem da queda, decorrente de um trajeto antropológico que coloca em relação as coerções do meio (desintegração familiar) e as pulsões do homem (pulsão de vida no desejo de viver em família), é suscetível a qualquer um e tende a levar o sujeito para os campos mais obscuros do ser e do imaginar. Recorrendo à reflexologia betchereviana, Gilbert Durand (2012: 112) afirma que o recém-nascido é imediatamente sensibilizado para a queda ao vir à luz, já que os movimentos bruscos que ocorrem no nascimento seriam "[...] a primeira experiência da queda e a primeira experiência do medo", concluindo, portanto, que "[...] haveria não só uma imaginação da queda, mas também uma experiência temporal, existencial" ligada a ela, "[...] o que faz Bachelard escrever que '[...] nós imaginamos o impulso para cima e conhecemos a queda para baixo"”. Durand (2012: 112) conclui que a queda é "[...] a quintessência

15. Que pode não ser realmente único, podendo haver "centros do mundo" diferentes dentro de uma mesma cultura, conforme demandas simbólicas específicas. 
vivida de toda a dinâmica das trevas". Além disso, explica que regressões psíquicas podem vir ligadas a fortes imagens de queda e cenas infernais. Por fim, resgata diversos mitos que ressaltam o "aspecto catastrófico da queda" (2012: 113), como os de Ícaro, Atlas, Tântalo, Faetonte, Ixíon e Belerofonte, todos caídos.

Mircea Eliade (2002) explica que a produção e a renovação constantes das imagens simbólicas que habitam o imaginário humano torna possível manter um canal aberto entre culturas aparentemente diferentes - o que renova e amplifica a polissemia das imagens e a efetividade das narrativas decorrentes delas. Entre alguns exemplos de recorrência e renovação simbólica, cita o mito da descida do herói ao inferno. Eliade argumenta que, apesar da descida ao inferno ser recorrente entre mitologias, ela tende a ter valorizações diferentes conforme culturas e religiões. O autor exemplifica o fato citando, por exemplo, o xamã que desce ao inferno para trazer de volta a alma do doente roubada pelos demônios, ou a jornada de Orfeu pelo Mundo Inferior em busca de sua esposa Eurídice (que acabara de morrer ${ }^{16}$ ) e também a polêmica descida de Jesus ao inferno em sua tentativa de restaurar a integridade do homem derrotado pelo pecado ${ }^{17}$. Porém, embora existam distinções, "[...] um elemento permanece imutável: a persistência do motivo da descida aos Infernos, que é realizada para a salvação de uma alma" (Eliade, 2002: 165), não importando que seja a alma de um doente (xamanismo), de uma esposa (mitos gregos, polinésios e centro-asiáticos) ou da humanidade inteira (cristianismo).

De fato, após sua trágica queda, Kurt desce a um inferno imaginário para salvar a própria alma. E esta imagem simbólica ganha expressão na realidade histórica, visto que é do submundo sócio-musical que surge uma alternativa de vida para ele. Por um lado, Kurt havia chegado a um limite de angústia, sofrimento e uso de drogas que o levaram a tentar o suicídio. Por outro lado, o roqueiro começava a transitar no underground cultural, espécie de Mundo Inferior onde o punk rock era a ordem. Com o rock, Kurt renasce.

\section{Nevermind, o simbolismo da água e o renascimento pelo rock}

Kurt volta a morar com a mãe por volta dos 15 anos, quando passa a dar mais atenção às composições e à guitarra. A irmã, Kim, diz que Kurt e o underground "se encontraram", dando a entender certo magnetismo entre ambos. Para ela, o irmão procurava ser parte de algo para se sentir menos só (2015,

16. Durand também aponta mitos análogos ao de Orfeu, que ocorrem na Polinésia, na América do Norte e na Ásia Central.

17. Passagem ainda polêmica entre religiosos e teólogos. 
27:14). Em uma entrevista não datada, respondendo à pergunta "por que você começou a ouvir punk rock?", Kurt afirma:

Eu sempre quis ouvir punk rock, mas claro que não havia isso na loja de discos de Aberdeen. Um amigo me deu umas fitas. Eu fiquei completamente espantado. Eu ouvia aquelas fitas todo dia. Era a melhor coisa. Expressava o que eu sentia socialmente, politicamente. Era a raiva que eu sentia diariamente. Então eu me dei conta que isso era tudo o que eu sempre quis fazer. Só o fato de realmente estarmos tocando música ao vivo em um quarto era incrível. Era a coisa mais inacreditável que eu já tinha feito. (Cobain: Montage of Heck, 2015: 27:17-28:15).

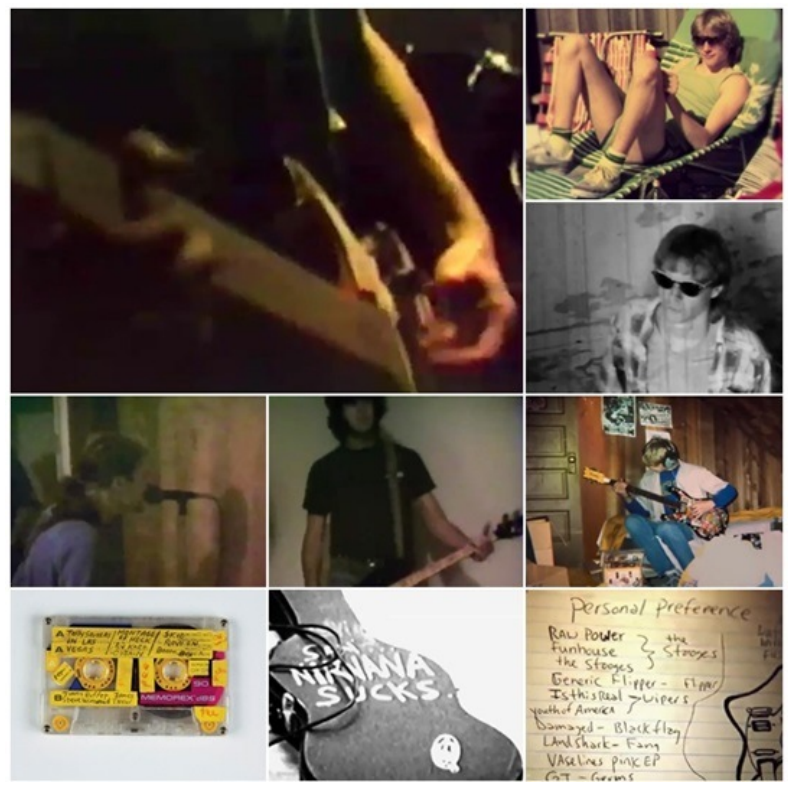

Figura 3. Fã de punk rock, como mostra sua lista de discos preferidos, Kurt ensaiava em um quarto com o baixista Krist Novoselic (ao centro) no início do Nirvana.

Reproduções: Cobain Montage of Heck (2015).

Nesta época, aos 17 anos, Kurt já tocava com Krist Novoselic, 18. Juntos formaram o Nirvana, última grande banda de rock'n'roll a surgir antes da consolidação da troca de arquivos de música digital. Alternando ensaios e shows com momentos caseiros de livre criação, incluindo composição musical, escrita, artes visuais e gravações em áudio, ${ }^{18}$ Kurt parece ampliar sua produtividade. Com o Nirvana um pouco mais consolidado, a banda assina com o

18. Como a própria fita experimental Montage of Heck, representada na montagem fotográfica acima. 
prestigiado selo independente Sub Pop para lançar o primeiro disco, Bleach (1989). Com isso, mais gente vai aos shows, cuja alta voltagem resultava em apresentações energéticas e ensurdecedoras. Já enraizadas no ruído metálico da guitarra, a angústia e a desilusão de Kurt Cobain agora tomavam sentido mais nítido e forma mais palpável. Pela música, Kurt passa a elaborar seus anseios. Porém, com turnês agendadas pelos Estados Unidos e pelo exterior, e com o assédio da imprensa especializada em punk e indie rock ${ }^{19}$ crescendo, Kurt parece saber que a celebração da mídia tende a desvirtuar a atenção do público para outros temas além do musical. Assim, questionado sobre o futuro do Nirvana nesta consolidação inicial da banda, o guitarrista responde destacando a maior importância da música sobre o todo.

O futuro do Nirvana? Eu não sei. Espero que seja tentar escrever algumas novas músicas boas. É isso o que nos importa. É compor boas músicas. Se nos tornarmos populares ou não, isso não importa. A música é mais importante. (Cobain: Montage of Heck, 2015, 47:21-47:35).

Krist comenta que Kurt tinha tendência ao perfeccionismo. "Ele odiava ser humilhado. Ele detestava isso. Se ele ao menos pensasse que havia sido humilhado então você veria a raiva aparecer" (2015, 49:47-49:59). Como consequência, o músico era cuidadoso ao apresentar sua arte, abdicando disso apenas por motivos de saúde. Enquanto a banda seguia seu percurso, Kurt começa a sofrer com problemas estomacais, admitindo que recorreu a drogas pesadas para controlar as dores. "Eu experimentei heroína pela primeira vez em 1987, em Aberdeen, e usei novamente umas dez vezes de 87 a 90. Por cinco anos, todos os dias, uma constante dor estomacal me levou literalmente ao ponto de querer me matar", diz em um bilhete escrito à mão, sem data de referência (2015, 51:45). Curiosamente, em uma entrevista, dá indícios sobre o motivo de não fazer um tratamento médico adequado: "Eu abriria mão de tudo para ter uma boa saúde. Mas tenho medo de, se perder o problema estomacal, talvez não me manter assim criativo" (2015, 52:18-52:32).

Apesar da doença de Kurt, o Nirvana parte para uma trajetória ascendente, sendo mais escutado, visto, comentado e consumido entre jornalistas, fãs, produtores e empresários. Kurt, no entanto, mantém seu discurso de antirrock star, diminuindo a opinião daqueles que já anunciavam a banda como a salvação do rock'n'roll:

É constrangedor haver tanta expectativa. É totalmente superficial rotular uma banda como the next big thing. Esse nem é nosso objetivo. As pessoas estão

19. Indie rock, abreviação inglesa para rock independente, vertente estética sonora de ampla linhagem alternativa que se fortaleceu nos anos 1990 especialmente depois da difusão do ideal punk 'do it yourself' dos anos 1970 e do apoio das college radios norte-americanas às novas bandas na década de 1980 . 
colocando essa etiqueta em nós sem que a gente queira. Não estamos preparados [para isso], porque não estaremos mesmo preparados. Não vamos nos preparar para destruir nossas carreiras. (2015, 54:40-55:06, grifo nosso).

Depois do disco de estreia, Bleach, ser lançado em 1989 pela Sub Pop, o álbum mais emblemático da banda, Nevermind, chega às lojas em 1991 após um acordo com a gigante Geffen Records, do Grupo Universal Music. Com o suporte da poderosa gravadora, hits como Smells Like Teen Spirit, Come as You Are e Lithium chegaram a dezenas de países do mundo por meio das rádios, da televisão e de CDs. O rock'n'roll cru do Nirvana, punk, seco e obsessivo, totalmente oposto ao rock tradicional e comercial que dominava as listas dos mais vendidos na época, alcança sucesso global. Não sendo esta uma meta declarada da banda, a fama pouco agrada a Kurt, que aproveita entrevistas para demonstrar seu desinteresse pela unanimidade e também seu desgosto com a capacidade da mídia em nomear e destruir ídolos (novos olimpianos) instantaneamente. Quando perguntado se ele percebia que as audiências dos shows estavam ficando diferentes com o passar do tempo, Kurt responde ambiguamente, posicionando-se entre a crítica ao consumo de cultura pop e a compreensão de que jovens naturalmente se identificam com músicos. Ele diz: “[...] todos querem ser hip ${ }^{20}$, todos querem ser aceitos" (2015, 01:04:31-01:04:43). Já em outra entrevista, ao falar sobre a sintonia entre roqueiros e seu público, bem como sobre o perfil dos fãs, Kurt explica que há uma conexão entre ambos: "Eu toco para jovens em geral. Não importa de onde eles vêm. Nós temos os mesmos problemas, e basicamente temos os mesmos pensamentos" (2015, 01:06:30-01:06:55).

Esta sintonia entre banda e fãs pode ter sido uma das origens estéticas e conceituais da capa de Nevermind (2015, 55:40), uma das mais conhecidas capas de disco do rock'n'roll. A fotografia que estampa a embalagem do disco, uma clara referência ao condicionamento capitalista a que somos submetidos desde o nascimento, desagradou à gravadora, mas foi aprovada. Surgida de uma ideia de Kurt, a foto mostra um bebê de três meses de vida mergulhando em uma piscina de água cristalina tendo a sua frente uma nota de um dólar fisgada em um anzol - e devidamente fora de alcance da criança. A imagem técnica emite uma primeira mensagem muito nítida, porém abaixo de sua significação imediata há sentidos de ordem imaginária movimentados pela ima-

20. Abreviação para hipster, termo que designa amantes do lado B (independente, autoral, autêntico e menos comercial) da cultura pop, incluindo cinema, música, artes visuais e gráficas, design, fotografia e moda. 
gem simbólica da água, substância ligada à imaginação material ${ }^{21}$ proposta por Gaston Bachelard (2013).

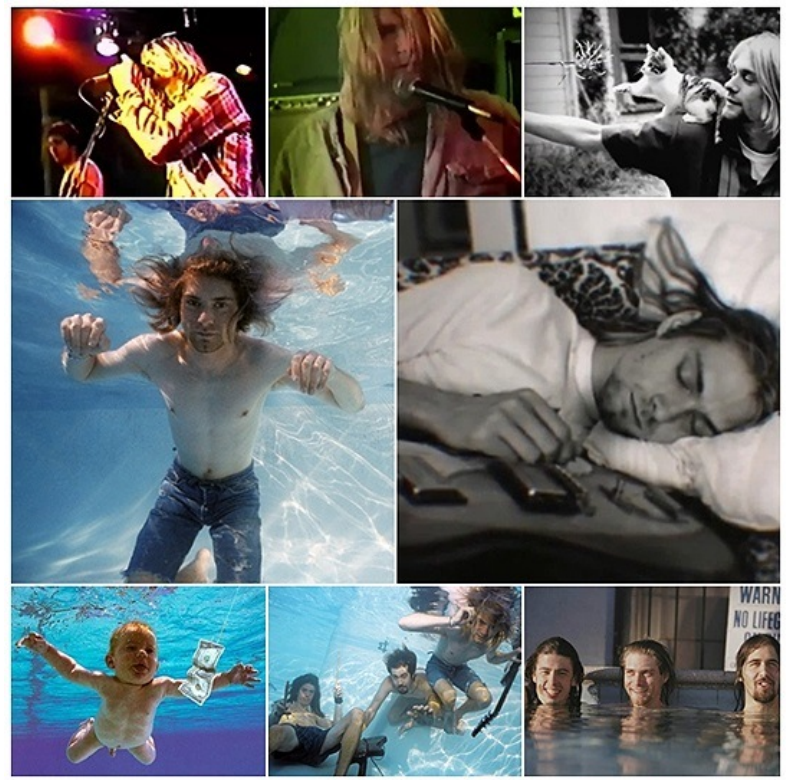

Figura 4. Kurt Cobain durante shows, em momentos de descanso e mergulhando com o Nirvana para um ensaio fotográfico de divulgação do disco Nevermind.

Reproduções: Cobain Montage of Heck (2015).

Juntamente com a foto da capa de Nevermind foi realizado um ensaio fotográfico com o Nirvana (2015, 55:40-56:05, Figura 4) para divulgação do álbum. Nele, os roqueiros também mergulharam com seus instrumentos em uma piscina de águas límpidas, movimentando sentidos de renovação, renascimento, purificação e transparência pós-queda simbólica de Kurt. Na fluidez elementar da água presente na fase Nevermind do músico há uma expressão simbólica do renascimento do guitarrista após sua descida infernal. Se antes Kurt estava preso à escuridão ameaçadora, envolto em dor e desespero, agora o guitarrista é revitalizado pelo simbolismo aquático. Nas águas claras, translúcidas e primaveris (Bachelard, 2013: 21) da capa de Nevermind e do ensaio fotográfico do Nirvana, a fluidez hídrica estimula sentidos de força vital, metamorfose e deformação das essências (como a própria essência do ser). Con-

21. Em seus estudos sobre a imaginação material, Bachelard (2013) desvenda as imagens poéticas estimuladas pelos quatro elementos da cosmologia grega (terra, água, ar e fogo). Para o autor, as imagens estimuladas pelos elementos surgem como resultado da ação do homem sobre a matéria do mundo. Para revelá-las, bem como seus sentidos e valorizações, Bachelard recorre às referências míticas e literárias destas substâncias na cultura humana 
forme Bachelard, estes sentidos estão ligados às valorizações positivas comuns ao líquido efêmero. As fotografias movimentam ainda um senso de águas calmas, acalentadoras, envolvedoras, que acolhem e purificam ${ }^{22}$ (Bachelard, 2013: 139). Neste momento, Kurt goza o sucesso de sua banda e encontra-se em certo apaziguamento com a angústia rotineira que o cerca, exorcizando no elemento aquoso a queda infernal da fase anterior.

Porém, este renascimento de Kurt, impulsionado pelo rápido sucesso global do Nirvana, não duraria muito tempo. O motivo pode ser observado em uma fala de Krist Novoselic sobre a reação à fama:

Acho que cada indivíduo lida com isso de uma forma. Foi meio traumático se tornar famoso de repente, especialmente vindo da completa obscuridade e depois se tornando a banda número um do mundo. Eu fiz coisas que eu pude, como beber. Eu tive sorte. Tive cerveja e vinho, sabe? Kurt tinha heroína. (Cobain: Montage of Heck, 2015, 01:11:20-01:11:44).

Conforme Krist, quando Kurt conheceu Courtley Love, sua futura mulher, ambos usavam drogas. Para o baixista, o amigo muito provavelmente tinha desejo de construir um lar novamente e, vendo Courtney como "[...] interessante, artística e intelectual", o fato dela manter um vício era "[...] parte do pacote de montar um lar" (2015, 01:12:29-01:12:39).

\section{A casa, a interioridade $\mathrm{e}$ a intimidade}

O documentário não esclarece quando Kurt e Courtney começaram a namorar, mas o Nirvana já despontava na cena rock mundial. Segundo Courtney, que admite no filme ter usado heroína por algum tempo até eventualmente se livrar do vício (2015, 01:14:58), Kurt nutria sentimentos autodestrutivos no período em que estiveram juntos. Conforme a ex-líder da banda Hole, "[...] ele tinha uma fantasia, que era: 'Eu vou ganhar US\$ 3 milhões e vou ser um junkie"" (2015, 01:15:15). Essas seriam as palavras do músico.

Entretanto, antes de executar esse plano trágico, cuja veracidade não foi comprovada pelo filme, Kurt e o Nirvana tornam-se ainda mais populares entre fãs de rock. O documentário intercala cenas de turnês norte-americanas com giros por países asiáticos e sul-americanos, incluindo trechos da famosa apresentação para cerca de 110 mil pessoas em um festival em São Paulo, no dia 16 de janeiro de 1993, na qual os músicos demoliram seus hits, tocaram covers arriscados, trocaram de instrumentos entre si e os destruíram depois. Este show dividiu opiniões, sendo considerado por parte do público e da imprensa brasileira como o pior espetáculo que a banda já havia feito até então

22. O exato oposto das águas escuras, turvas, profundas, agitadas e ameaçadoras, que movimentam amplas valorizações negativas. 
e, por parte da crítica e de fãs do trio como um imprescindível ato caótico de anarquia e catarse. ${ }^{23}$

Kurt estava desapontado com a exposição massiva do Nirvana e com o sucesso repentino da banda pelo mundo. Em uma entrevista para um canal de TV, deixa transparecer sua insatisfação. "É legal ser famoso?", perguntam. "Pessoas realmente famosas acabam totalmente reclusas, fazendo nada. É um saco!" (2015, 01:16:03-01:16:15), responde. O Nirvana, que poucos anos antes tocava dentro de um quarto para alguns amigos, já considerando isso um ótimo show, segue rapidamente dos pequenos bares de Seattle para longas turnês internacionais que incluíam participação em megafestivais patrocinados por multinacionais cujos projetos nem sempre agradavam ao trio. Kurt percebia o quadro geral.

Com Nevermind chegando ao topo da Billboard (2015, 01:19:40) e várias músicas bem executadas nos Estados Unidos entre 1991 e 1996, shows do Nirvana acabam sendo cancelados na Europa devido ao que seriam crises estomacais de Kurt. Porém, em entrevista, Courtney afirma que naquela época ele queria apenas ficar em casa sofrendo, usando heroína e tocando guitarra. Ela não esclarece se o músico de fato passava por problemas de saúde (2015, 01:20:15-01:20:40).

Em meio às atividades do Nirvana e aos dilemas pessoais, Kurt se casa com Courtney, ambos montam uma casa e passam a viver juntos. Com a mulher que ama (2015, 01:24:00), Kurt exercita a construção de um lar, retomando um ideal perdido com a separação dos pais. Agora, após a dissolução familiar de sua infância, o guitarrista tinha novamente uma casa. Nela, vivia com sua mulher, que em breve daria à luz Frances Bean Cobain, filha do casal. Com o nascimento da menina, após uma polêmica gestação durante a qual Courtney confirma ter usado heroína, Kurt conclui sua busca pelo sonho de família. Agora, ao lado da sua, ele recupera seu "centro de mundo".

Portanto, a casa de Kurt, a residência Cobain, ${ }^{24}$ lócus ideal para a vida em família ${ }^{25}$, ativa a própria imagem arquetípica da casa. Esta, por sua vez, estimula imagens simbólicas de interioridade, sejam elas mais nítidas, vertidas

23. Conforme entrevista de Krist Novoselic publicada na Folha de S. Paulo um dia após a apresentação no Hollywood Rock, cujo trecho recuperado pelo $U O L$ em 2013 é reproduzido aqui, aquele "foi um show de desconstrução de imagem do grupo". Anos depois, em entrevista ao blog Popload, o baterista Dave Grohl diz considerar aquele show inesquecível pela loucura da situação, incluindo um Kurt Cobain cantando e tocando sob o efeito de vários comprimidos de Valium: "Foi inacreditável. Foi insano". Para mais informações sobre esta apresentação, conferir a biografia Mais Pesado que o Céu, de Charles R. Cross, além de críticas e reportagens publicadas pelos principais veículos de comunicação do Brasil.

24. Tanto a casa antiga, dos pais de Kurt, quanto sua residência atual, com Courtney.

25. Como fica devidamente registrado nos muitos vídeos caseiros gravados pelo casal (2015, 01:20:45-01:24:00). 


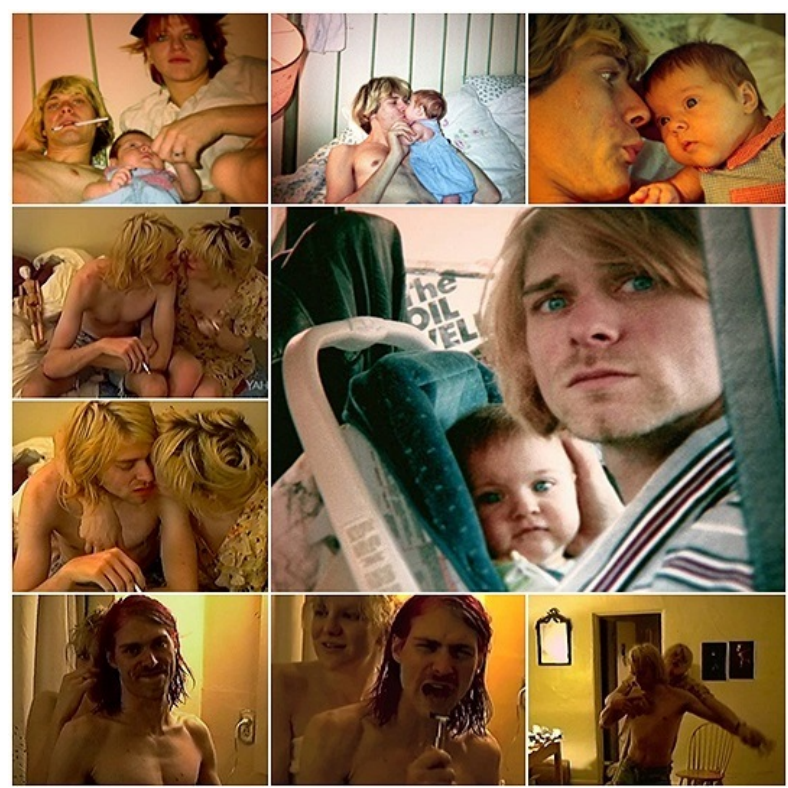

Figura 5. Kurt Cobain com a mulher, Courtney Love, e com a filha, Frances Bean, em sua casa.

Reproduções: Cobain Montage of Heck (2015).

no mundo sensível à morada, palácio, templo e claustro, por exemplo, ou então mais ambivalentes, dotadas de sentidos ambíguos e complementares como cave, concavidade, ventre materno, penetração, enterramento, gruta, sepulcro, túmulo, retorno, descanso. Durand (2012: 241) retoma dados sobre simbolismo arcaico oferecidos por Eliade para mostrar como muitas destas imagens constelam para propor sentidos sobre vida e morte - sendo vida uma espécie de separação natural da terra para a vivência no mundo, e morte um retorno à casa para sepultamento na terra natal.

A vida não é mais do que a separação das entranhas da terra ${ }^{26}$, a morte reduzse a um retorno à casa... o desejo tão frequente de ser enterrado no solo pátrio não passa de uma forma profana de autoctonismo místico, da necessidade de voltar a sua própria casa ${ }^{27}$ (Eliade apud Durand, 2012: 236).

Assim, Durand entende que há um "[...] isomorfismo do retorno, da morte e da morada" (2012: 236), bem como um "[...] isomorfismo que liga o ven-

26. A terra aqui poderia ser entendida como elemento material, substância, mas também como imagem simbólica da mãe elementar, telúrica, que guarda em si tanto a capacidade criadora de vida quanto o poder continente pós-morte.

27. Importante lembrar que Kurt Cobain cometeu suicídio em sua casa em Seattle. 
tre materno, o túmulo, a cavidade em geral e a morada fechada" (2012: 242). Todas estas imagens, entre tantas outras, convergem no simbolismo de intimidade - o qual articula sensos diversos, incluindo o prazer das delícias privadas, dos domínios aconchegantes, do repouso e da quietude.

Conforme os depoimentos e registros apresentados no documentário, Kurt buscava ter novamente uma casa, um lar, que se sobrepusesse à casa e ao lar dos pais, e onde pudesse finalmente atualizar ritos familiares interrompidos, perdidos em um passado estagnado que ainda provocava angústia - mas que, contraditoriamente, o ajudava a dinamizar seu ato criativo. A imagem simbólica da casa, então, sendo um dos elementos preponderantes do imaginário humano como um todo, também toma dimensão importante no próprio imaginário movimentado por Kurt Cobain ao se refletir tanto no sonho da residência de infância quanto no ideal da nova morada de casado.

Se recorrermos novamente a Bachelard, veremos que sua poética do espaço desenvolve-se sobre vários locais, mas se manifesta principalmente na sua casa de campo natal, em Bar-sur-Aube, na França. O motivo parece bastante claro: Bachelard entende que a casa mais adaptada à poética é aquela em que vivemos - especialmente a da nossa infância. Diz o autor que "[...] com a imagem da casa temos um verdadeiro princípio de integração psicológico [...] parece que a imagem da casa se torna a topografia de nosso ser íntimo" (Bachelard apud Wunenburger, 2012: 57 e 58). Kurt, apesar da incompreensão com o fim do casamento dos pais e com a desestruturação familiar, manteve seus desejos de lar e união fazendo transcender no seu "centro do mundo", aquele centro estimulado pela família, ${ }^{28}$ a imagem arquetípica da casa e os possíveis sentidos que esta propõe a ele.

Seja a casa em que se nasce e cresce ou aquela onde se constitui família na fase adulta, as emanações simbólicas de interioridade e intimidade decorrentes dela e observadas por Durand costumam se expressar na Estrutura Mística (ou Antifrásica) do Regime Noturno do imaginário. A Estrutura Mística, marcada pelo apaziguamento do homem com a certeza da morte, nossa angústia essencial, compreende também símbolos relacionados à introspecção, aos mistérios, aos segredos e aos devaneios, além daqueles que remetem à fusão, união, mistura e concentração.

É esta casa estimulante do interior arquetípico e da intimidade simbólica, este lócus de segurança propício à transcendência por imagens, o local onde Kurt se refugia para atualizar os ritos familiares que ativam seu "centro de mundo". Com isso, o músico busca preencher aquele vazio que havia se insta-

28. Como visto na p. 11 deste artigo, o "centro do mundo" proporciona revelações de sentido e orienta a transcendência de imagens pregnantes, atualizando-as constantemente. 
lado no simbolismo do centro movimentado pelo guitarrista ${ }^{29}$. Em sua casa, seu lar, com sua nova família, Kurt pode experimentar movimentos de agregação característicos da Estrutura Mística do imaginário, como os já citados fundir, unir, misturar e concentrar - sejam imagens, sentidos, ideais, sonhos, desejos ou anseios.

\section{$O$ amor e a morte: uma segunda queda}

O documentário registra a vida de Kurt e Courtney apresentando fotografias, vídeos, versos e pequenos textos escritos pelo casal, como um no qual ele afirma: "Courtney, quando digo que te amo eu não sinto vergonha, e ninguém jamais chegará perto de me intimidar para pensar o contrário" (2015, 01:24:03). Em outra anotação ela escreve: "Eu amo você mais do que a minha mãe. Eu abortaria Cristo por você. Eu poderia me tornar miserável para fazer você feliz" (2015, 01:24:36). As declarações não deixam dúvidas sobre os níveis viscerais, urgentes e trágicos deste amor. Ao filme, Courtney diz que os dois queriam ter filhos, e que se casou grávida de Kurt. "Nós já tínhamos [um filho sendo gestado]. Então, fazer uma família o mais rápido possível era, você sabe, importante. Se tivéssemos mais tempo eu teria tido mais filhos com ele" (2015, 01:24:38-01:25:00, grifo nosso).

Em um dos muitos home videos gravados por Courtney, vários deles nos quais o casal exerce seu poder de (auto)crítica, (auto)ironia e (auto)análise, ela pergunta a ele, jogado em uma cama, "Por que sente-se tão mal?", ao que ele responde de forma propositalmente piegas "Por quê? Porque eu quero. É minha culpa. Tooooda minha!" (2015, 01:25:03-01:25:15). Por trás da sátira pessoal, há sinais de que Kurt direcionava suas condutas com discernimento. Há conversas ácidas sobre conhecidos, sociedade, música, mídia e suas interrelações (2015, 01:25:15-01:27:53). Há o que poderíamos chamar de home performances ${ }^{30}$ e também joke interviews, sendo que estas poderiam ser entendidas não como entrevistas falsas ou mock interviews ${ }^{31}$, mas sim como pequenas encenações em que Kurt e Courtney se expressam pela voz de semipersonagens interpretados pelo casal, como se fossem dois rock stars superjun-

29. Como visto na p. 12 deste texto.

30. Há duas interessantes home performances registradas neste estudo. Em uma cômica, Courtney faz uma inspirada leitura dramática de uma carta supostamente escrita por uma amiga ou fã reclamando das atitudes de Kurt que fariam Courtney sofrer. A câmera registra a leitura dela, que dubla a interpretação muda de um Kurt magérrimo, de cabelos vermelhos e bigode nazista estilo Hitler, vestido de mulher e agindo como se fosse a menina que teria escrito a tal carta (2015, 01:27:53-01:28:48). Já numa home performance musical, o casal age como se estivesse sob efeito químico, fazendo música segundo um processo de desconstrução musical e de destruição guitarrística (2015, 01:29:38-01:30:42).

31. Mock interviews poderiam ser entendidas como entrevistas simuladas que servem como treinamento para entrevistas reais. 
kies, espécie de alter egos cujas falas amplificam a (auto)crítica e a (auto)ironia natural dos músicos (2015, 01:28:50-01:29:38).

O documentário não explica se, nestes vídeos caseiros, Kurt e Courtney estavam sob o efeito de drogas. É possível que sim, mas não há confirmação alguma sobre isso no filme. Entretanto, Courtney explica a dependência de heroína por parte de ambos:

Eu usei heroína quando estava grávida e então parei. Eu sabia que ela (Frances Bean) estaria bem. Ele jamais se preocupou que nossa filha teria... Eu $\mathrm{o}$ assegurei que levaria a gravidez adiante sem problemas, mas você sabe, eu era uma jovem mulher. A gravidez não era o problema. Era estar perto de um junkie enquanto eu estava grávida, sendo eu também uma junkie, e sabendo que assim que o bebê nascesse eu iria me drogar para celebrar, sabe? Esse era nosso estilo de vida. (Cobain: Montage of Heck, 2015, 01:30:35-01:31:11, grifo nosso).

A atenção excessiva da mídia ao Nirvana e especialmente aos momentos mais loucos de Kurt e Courtney incomodava o guitarrista. A sua crise com a imprensa chegou ao ápice após uma reportagem da revista Vanity Fair (2015, 01:32:40) sobre o uso de drogas pelo casal durante a gestação de Frances Bean. Furioso, Kurt escreve que se sentiu violado (2015, 01:33:33), condena o mau jornalismo, dispara cartas com ataques à imprensa e classifica a TV como "entidade de todos os deuses corporativos" (2015, 01:33:54). Paralelamente, o documentário apresenta textos que revelam a profunda angústia pela qual o músico passava:

Eu escuto tantas histórias e relatos exagerados de amigos sobre como sou notoriamente fucked up. Viciado em heroína, autodestrutivo, alcoólatra e ainda assim abertamente sensível, delicado, frágil, neurótico, meio insignificante, que a qualquer minuto vai ter uma overdose, ${ }^{32}$ pular do telhado e explodir a cabeça, tudo de uma vez só. (Cobain: Montage of Heck, 2015, 01:34:07-01:34:34)

Em áudio, Kurt admite que sua história tinha propensão à tragédia. "Eu pensava que as pessoas queriam que eu morresse, pois seria a clássica história rock'n'roll' (2015, 01:34:44-01:34:50). Neste momento (2015, 01:35:00), o filme volta ao seu ponto inicial em que Kurt encena sua morte durante um show. Naquele mesmo palco, o músico reclama publicamente do que "tem sido escrito" sobre eles, diz que Courtney acha que todos a odeiam, e pede que a multidão grite "Courney, I Love you". Atendido pelo público, Kurt puxa a conspiratória Territorial Pissings, na qual canta "Just because you're paranoid

32. Kurt escreve "[...] neurotic, little pissant who at any minute is going to O.D.”. A abreviação O.D., conforme o conhecido portal online UrbanDictionary.com, pode ser entendida como "overdose on a drug", "over-doing"ou "overdosage". 


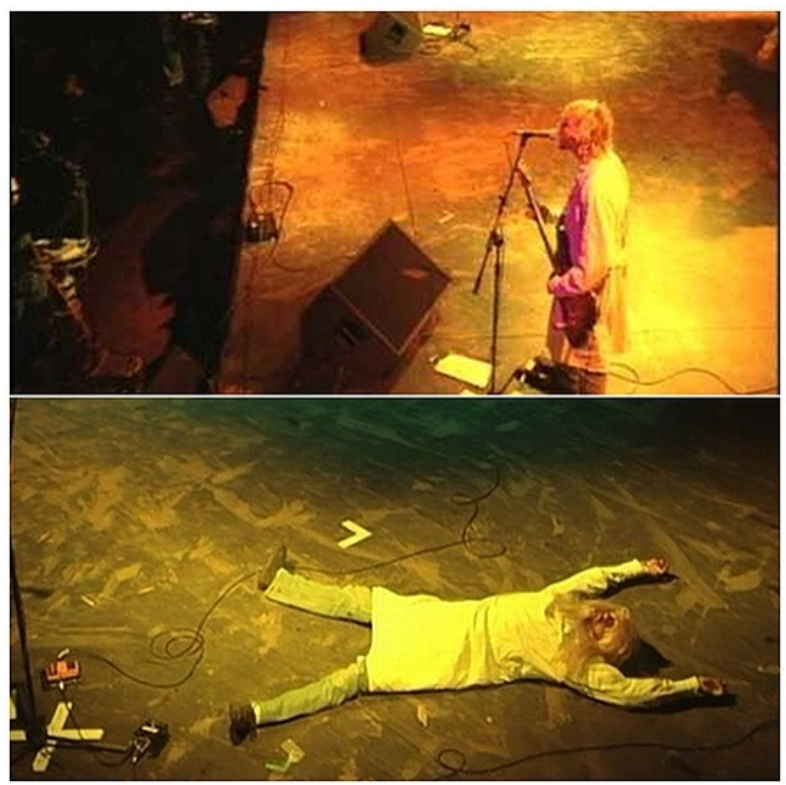

Figura 6. Kurt encena sua morte durante show no megafestival inglês Reading em 1992.

Reproduções: Cobain Montage of Heck (2015).

don't mean they're not after you". ${ }^{33}$ Nisso, o documentário resgata notícias sobre o nascimento de Frances e o monitoramento governamental sobre a criação da menina (2015, 01:38:21).

A dureza dos relatos jornalísticos é contraposta a vídeos caseiros sobre a doce vida em família, nos quais o casal cuida da filha. Kurt dá atenção e carinho à criança e Courtney se mostra uma mãe amorosa (2015, 01:38:3201:40:10). A respeito da paternidade, Kurt escreve: "Eu escolhi me colocar em uma posição que requer a maior responsabilidade que alguém pode ter. [...] Farei de tudo para lembrá-la que a amo mais do que amo a mim mesmo" (2015, 01:40:45). Em áudio, diz ter certeza que pode mostrar muito mais afeto do que seu pai foi capaz, e que só Frances poderia afastá-lo do rock'n'roll (2015, 01:41:00-01:41:43). Porém, ao mesmo tempo em que exercita o afeto pela filha, Kurt segue em aflição, deprimido e irritado pela perseguição da mídia e pelo que seria a publicação de informações falsas sobre sua família (2015, 01:44:00-01:45:12). Ele escreve:

33. "Só porque você é paranoico não significa que eles não estejam atrás de você". 
Sonhos ruins, estômago vazio. Acordo pela manhã sentindo-me envenenado. Durante sonhos ruins, nervos vazam toxinas cerebrais que fluem pelas veias engrossando lentamente, ao ponto de um veneno poderoso, vagarosamente coagulando como uma pluma caindo nas chamas. (Cobain: Montage of Heck, 2015, 01:45:30).

E segue em outros escritos: "Enterrado fundo em um sonho de heroína [...] eu fiquei tão chapado que arranhei até sangrar" (01:45:38). Ou ainda: "Não me importo se eu murcho sozinho, eu não me preocupo se eu não tenho uma mente" ${ }^{34}(01: 45: 52)$.

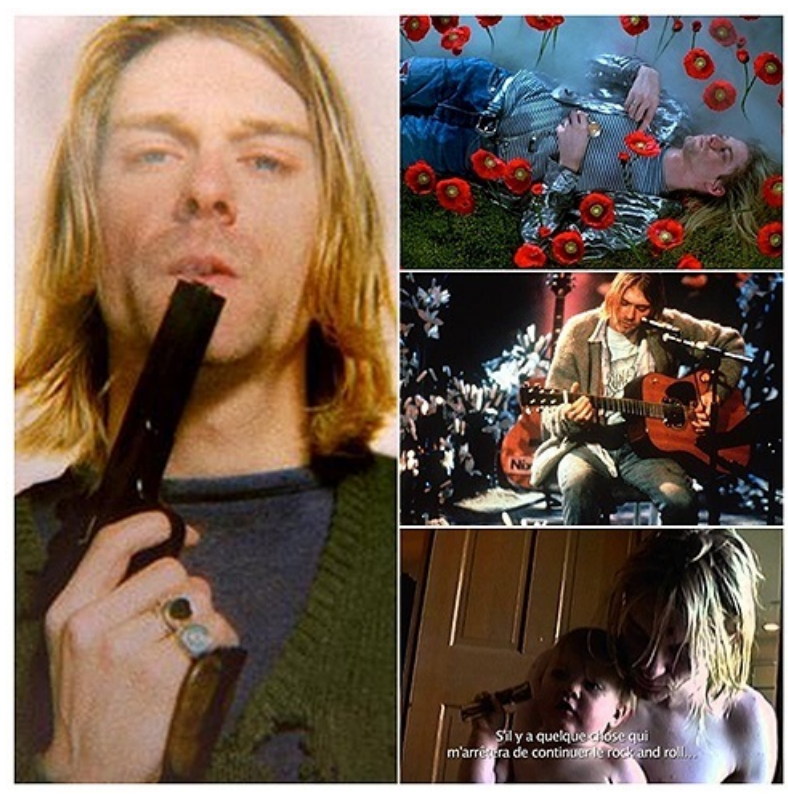

Figura 7. Kurt empunha uma arma de fogo em seu último ensaio fotográfico, assinado por Youri Lenquette e realizado em Paris dois meses antes do seu suicídio em abril de 1994, em Seattle. Acima, cena lúgrube do clipe da música Heart Shaped Box, do disco In Útero (1993). Ao centro, clima de velório no Unplugged MTV (1993). Abaixo, prejudicado pela heroína enquanto Frances ainda era bebê.

Reproduções: Cobain Montage of Heck (2015).

No período de composição e gravação do disco In Utero (1993), mesma época do show da banda no Brasil citado anteriormente, Kurt altera momentos de criatividade e infelicidade. Havia acabado de sair de um momento em que "[...] estava de saco cheio de tudo", que "[...] não queria ser um rock star" e que "[...] estava ficando assustado" (2015, 01:49:45-01:49:58). Em um ensaio

34. No original: "I don't care if I shrivel alone. I don't mind if I don't have a mind". 
fotográfico, é clicado manejando um revólver (2015, 01:49:18; Figura 7). Já um vídeo caseiro da época em que Frances ainda era bebê registra Kurt bastante fragilizado, magro e abatido, quase dormindo em pé enquanto segura a filha no colo (2015, 01:52:17-01:54:50). Para a mãe do músico, seu quadro piorava a cada dia e ele sentia vergonha por isso (2015, 01:54:50-01:56:50). Durante a gravação do programa Unplugged MTV, cuja cenografia com velas e lírios lembrava a decoração de um velório, Kurt disparou contra o público: "[...] Todos que eu conheço podem sentar aqui na frente para que eu possa vê-los? Porque eu odeio estranhos..." (2015, 01:58:30).

Courtney afirma que Kurt tentou se matar ${ }^{35}$ após o que teria sido uma tentativa de traição por parte dela, em Londres - o caso extraconjugal não teria ocorrido (2015, 02:03:55). Conforme o jornal The Daily World, citado pelo documentário, após tomar o medicamento ripnol com champanhe o guitarrista entrou em coma, sendo levado à emergência de um hospital em Roma. Ao som acústico de Where Did You Sleep Last Night? ${ }^{36}$, o filme intercala frases soltas escritas por Kurt: "O melhor dia que eu já tive foi quando o amanhã nunca chegou", "Mate-se, mate-se, mate-se!", "Eu me odeio e quero morrer. Me deixe em paz. Com amor, Kurt" (2015, 02:05:56-02:06:09).

Conforme o documentário, Kurt Cobain cometeu suicídio um mês após a volta da capital italiana, no dia 05 de abril de 1994, aos 27 anos, em Seattle. O filme se encerra neste momento, não entrando em detalhes sobre a causa da morte nem sobre as investigações policiais que se seguiram. Também não debate as teorias conspiratórias sobre o caso, incluindo aquelas relativas ao suposto envolvimento de Courtney no que teria sido o assassinato do marido ${ }^{37}$. Por outro lado, o filme apresentou documentação, pesquisa e depoimentos registrando o amor entre Kurt e Courtney e sua tentativa de estabelecer uma família. Ainda assim, a angústia e a depressão amplificadas pelo abuso de drogas por parte do músico emitem imagens e sentidos frequentes de trevas, desespero, aniquilação e morte, expressos tanto em sua música e composições textuais quanto em sua trajetória de vida.

Porém, se para Durand a passagem do tempo e a consciência sobre a morte estimularam o homem a criar imagens ao longo da sua existência, de forma a elaborar esses problemas e dar sentido à vida, Kurt abdica de sua imaginação criadora ao sucumbir à pulsão de morte potencializada pelo sofrimento existencial e pela dependência química. Ao tirar a própria vida, o guitarrista

35. Segunda tentativa, conforme o documentário.

36. Música de Huddie Ledbetter.

37. Tema de documentários como Kurt \& Courtney (1998), de Nick Broomfield, e Soaked in Bleach (2015), de Benjamin Statler. 
provoca sua segunda queda simbólica, igualmente física e moral, porém desta vez totalmente inescapável.

\section{Do imaginário de um roqueiro ao imaginário rock}

A proposta de leitura simbólica de Cobain: Montage of Heck dá indícios sobre como, de fato, roqueiros como Kurt Cobain assumem condutas pessoais e tomam percursos antropológicos cujos movimentos podem estimular imagens arquetípicas, simbolismos, traços míticos e metáforas obsessivas constitutivas de um imaginário roqueiro conectado ao amplo imaginário humano cujos elementos são compartilhados há gerações.

Porém, este imaginário rock não é marcado somente pelos clichês do estilo musical disseminados pela mídia. Sua pregnância é efetivada justamente por alguns dos elementos ancestrais que transitam no grande sistema de imagens polissêmicas observado por Durand em consonância com pensadores como Jung, Eliade e Bachelard. Se levarmos em conta que este imaginário antropológico encontra-se em ampla retroalimentação, oferecendo imagens simbólicas e narrativas míticas para os indivíduos e as culturas estabelecerem entendimentos de mundo, condutas pessoais, movimentos sociais e estruturação de realidades, devemos observar que este mesmo imaginário se nutre continuamente das imagens simbólicas e técnicas elaboradas pelos sujeitos e veiculadas em produtos culturais.

No caso da leitura simbólica sobre as representações documentais propostas por Cobain: Montage of Heck, entendemos que o ex-líder do Nirvana movimenta um imaginário revelador de um "centro do mundo"definido pela família - tanto aquela instaurada e dissolvida pelos seus pais quanto aquela construída pelo próprio músico após seu casamento e o nascimento da filha. Este "centro do mundo"familiar moldou o percurso do guitarrista no mundo, provocandolhe pelo menos duas quedas infernais das quais em apenas uma resultou em um renascimento pelo rock. A família e seu senso de união, solidificação e continuidade, cujo sentido ganha mais nitidez a partir da imagem arquetípica da casa e do simbolismo de intimidade, além do próprio amor declarado por Courtney e Frances Bean, porém, não foram suficientes para salvar Kurt. Dividido entre o profundo afeto pela família e a desilusão abismal com sua própria condição existencial, o guitarrista não escapa do vácuo provocado pelo simbolismo catamórfico.

Portanto, rock docs se colocam como importantes instrumentos audiovisuais cujos personagens, documentos, discursos e histórias movimentam conteúdos simbólicos arquetípicos cuja pregnância oferece sentidos múltiplos - e cujas constelações compõem o grande imaginário humano sistematizado por 
Durand. No caso de Cobain: Montage of Heck, entendemos que a simbologia estimulada por Kurt liga-se a um amplo imaginário rock que aguarda revelação.

\section{Referências bibliográficas}

Bachelard, G. (2013). A água e os sonhos. São Paulo: Martins Fontes.

Bachelard, G. (2001). A terra e os devaneios da vontade: ensaio sobre a imaginação das forças. São Paulo: Martins Fontes.

Bachelard, G. (1990). O ar e os sonhos. São Paulo: Martins Fontes.

Baitello Jr., N. (2014). A era da iconofagia - Reflexões sobre imagem, comunicação, mídia e cultura. São Paulo: Paulus.

Durand, G. (2000). A imaginação simbólica Lisboa: Edições 70.

Durand, G. (2012). As estruturas antropológicas do imaginário: introdução à arquetipologia geral. São Paulo: Martins Fontes.

Eliade, M. (2002). Imagens e Símbolos - Ensaio sobre o simbolismo mágicoreligioso. São Paulo: Martins Fontes.

Eliade, M. (1992). O Sagrado e o Profano. São Paulo: Martins Fontes.

Flusser, V. (2011). A filosofia da caixa preta - Ensaios para uma futura filosofia da fotografia. São Paulo: Annablume.

Jung, C.G. (1978). O Eu e o inconsciente. Petrópolis: Vozes.

Jung, C.G. (2002). Os arquétipos e o inconsciente coletivo. Petrópolis: Vozes.

Morin, E. (1997). Cultura de Massas no Século XX: Neurose. Tradução de Maura Ribeiro Sardinha - 9. Ed.. Rio de Janeiro: Forense Universitária.

Ramos, F.P. (2013). Mas afinal... o que é documentário?. São Paulo: Editora Senac.

Wisnik, J.M. (1999). O som e o sentido. Uma outra história das músicas. São Paulo: Companhia das Letras.

Wunenburger, J.-J. (2012). Gaston Bachelard, poétique des images. Paris: Mimesis. 